\title{
Bancos na Transição Republicana em São Paulo: O Financiamento Hipotecário (1888-1901)
}

\author{
- Renato Leite Marcondes* - Anne G. Hanley **
}

\begin{abstract}
Resumo
A transição republicana introduziu grandes transformações na economia brasileira e, principalmente, na paulista, marcadas pela abolição da escravidão, pelo crescimento da imigração estrangeira, pela expansão cafeeira e por reformas monetárias conduzidas pelo governo central. Nesse momento, a cidade de São Paulo tornou-se um grande centro destas mudanças. As instituições bancárias consistiram em agentes importantes no mercado financeiro. Analisamos a atuação dos bancos no fornecimento do crédito hipotecário na cidade de São Paulo de 1888 a 1901 . Nossa pesquisa cruza os balanços contábeis dos bancos com o registro hipotecário, a fim de investigar o perfil e o comportamento do crédito institucional de longo prazo durante uma era crítica da história de São Paulo. Argumentamos que o mercado hipotecário nessa época foi significativamente mais amplo e diversificado do que apontaram os estudos anteriores a respeito do desenvolvimento bancário e econômico. Os bancos hipotecários foram a fonte mais importante de financiamento no mercado paulistano, mas se retraíram rapidamente, ao final da década de 1890. Os bancos comerciais emprestaram recursos mediante hipotecas por períodos mais longos do que era típico para esta espécie de instituição. Mesmo os bancos comerciais estrangeiros atuaram neste mercado, apesar das advertências das matrizes para as transações com horizonte longo de tempo. Isto sugere que o mercado hipotecário foi suficientemente lucrativo para induzir estas instituições mais conservadoras a assumirem algum grau de risco.
\end{abstract}

\section{Palavras-Chave}

bancos, mercado de capitais, hipotecas, São Paulo, encilhamento

\begin{abstract}
The republican transition introduced great changes to the Brazilian and especially São Paulo economy, through abolition of slavery, immigration promotion programs, coffee boom and monetary reforms. At this moment, the city of São Paulo became a great center of these changes. The banking institutions consisted of important agents in the financial market. We analyze the performance of the banks in the supply of the mortgages loan in the city of São Paulo of 1888 the 1901. Our research crosses bank balance sheets with mortgage registries to investigate the profile and behavior of institutional long term credit during a critical era in Sao Paulo's history. We argue that the mortgage market at this had dramatic expansion and diversified of what they had pointed the previous studies regarding the banking and economic development. Mortgage banks were the single most important source of mortgage lending in the paulistano market, but sharply curtailed their new loan writing toward the end of the 1890 s. Commercial banks lent money in mortgages for longer time periods than was typical for this type of institutions. Even foreign commercial banks, which were warned away from transactions with long time horizons, entered this market.
\end{abstract}

\section{Keywords}

banks, capital markets, mortgages, economic history of São Paulo

\section{JEL Classification}

N26

* Professor da FEA-RP/USP. Endereço para contato: Av. dos Bandeirantes, 3900. FEA-RP - Bloco C - Sala 73 - Ribeirão Preto - SP. CEP: 14040-900. E-mail: rlmarcon@usp.br.

** Department of History. Endereço para contato: Northern Illinois University, DeKalb, IL 60115 - EUA. E-mail: ahanley@niu.edu.

(Recebido em setembro de 2008. Aceito para publicação em maio de 2009). 
Os anos da transição do Império à República caracterizaram-se por significativa turbulência política e econômica e até mesmo por conflitos armados expressivos. No campo econômico, o Brasil, e especialmente São Paulo, passaram por grandes transformações, marcadas principalmente pelo crescimento da imigração estrangeira, pela expansão cafeeira e por reformas monetárias, conduzidas pelo governo central. A principal política econômica do período foi o Encilhamento, caracterizado por uma expressiva expansão monetária e, como veremos adiante, financeira, entre 1888 e 1892. ${ }^{1}$ Nesse momento, a capital paulista tornou-se um grande centro destas mudanças, e as instituições bancárias consistiram em agentes importantes do mercado financeiro, assumindo papel central no Encilhamento.

Analisamos a atuação dos bancos no fornecimento do crédito hipotecário na cidade de São Paulo, de 1888 a 1901, examinando a participação das instituições bancárias nesta forma de crédito durante a transição republicana. Argumentamos que o mercado hipotecário dessa época foi significativamente mais amplo e diversificado do que apontaram os estudos anteriores a respeito do desenvolvimento bancário e econômico. ${ }^{2}$ Os bancos universais ou hipotecários mantiveram-se como os mais importantes durante todo o período. Apesar de os bancos comerciais não possuírem os instrumentos especializados para o financiamento hipotecário, buscavam realizar hipotecas como uma forma de melhor garantir os seus empréstimos. Contudo, como veremos adiante, as condições de financiamento destes bancos continuavam centradas em juros mais elevados e prazos mais curtos do que os dos bancos universais ou hipotecários. No final do período em estudo, os bancos comerciais ganharam participação no mercado, em detrimento dos hipotecários. Assim, a hipoteca revelou-se um meio importante para o financiamento dos mais variados tipos de instituições bancárias, porém limitada pelas restrições ao crédito de longo prazo, presentes na economia brasileira.

Utilizamos, como fonte primária, os livros cartorários de registro hipotecário e os balanços contábeis dos bancos, publicados nos jornais do município, que se encontram depositados no Arquivo do Estado de São Paulo. ${ }^{3}$ De início, fornecemos uma visão geral da legislação bancária e do mercado hipotecário na segunda metade do século 19. Ademais, caracterizamos a expansão dos vários tipos de bancos no período em que participaram do mercado hipotecário, contemplando os de natureza

1 Para uma discussão da política implementada e da crise financeira posterior, ver John Schulz (1996). Sobre o Encilhamento na cidade de São Paulo, consultar o trabalho de Lerias (1988).

2 Ver, por exemplo, Flávio Saes (1986), Gail Triner (2000) e Anne Hanley (2005). Tais estudos mostram a importância dos bancos na economia brasileira durante o Império e a Primeira República. Contudo, eles se basearam em fontes que revelam poucas informações mais detalhadas da participação bancária no mercado hipotecário, nesta primeira década republicana.

3 Muitos balanços e dados bancários foram fornecidos a Anne Hanley por Flávio Saes, a quem agradece. 
comercial, universal ou hipotecário e até mesmo algumas instituições estrangeiras. ${ }^{4}$ Posteriormente, apresentamos a dinâmica do crédito hipotecário dos diferentes tipos de bancos, no período, por meio do volume de crédito concedido, prazos e taxa de juros, condicionada fortemente pela conjuntura econômica. Ainda nesta seção, discutimos a importância das novas hipotecas nos ativos dos balanços contábeis de alguns bancos.

\section{Legislação Bancária e Mercado Hipotecário}

No final do século 19, o financiamento bancário brasileiro foi condicionado pelas mudanças na legislação e pela política macroeconômica imperial e republicana. $\mathrm{O}$ Código Comercial de 1850 e suas modificações posteriores regularam as práticas gerais das operações bancárias, que permitiram a expansão do crédito comercial. As leis hipotecárias de 1864 e 1890 estimularam os empréstimos de longo prazo. Ademais, as leis empresariais de 1882 e 1890 facilitaram a formação de sociedades anônimas (S/A), estimulando a expansão das instituições bancárias nas últimas décadas do século. Estes arranjos legais refletiram as tendências da política econômica do governo imperial e republicano. Os governantes do Império procuraram criar instituições para fomentar o crédito formal na economia brasileira, mas não alteraram o papel central do setor exportador e sua importância no comércio internacional. De outro lado, os republicanos promoveram mais ímpeto à economia doméstica, aprovando leis para estimular um crescimento mais amplo do crédito.

A natureza relativamente conservadora da política econômica imperial mostra-se perceptível em todas as três leis que regularam os bancos, e nas complementares, que regeram a formação de companhias por ações. O Código Comercial de 1850, que, pela primeira vez, definiu formalmente os bancos e seus principais negócios, procurou nada mais do que institucionalizar as práticas mercantis e os instrumentos de crédito pessoal utilizados no mundo dos negócios. ${ }^{5} \mathrm{O}$ código regulamentou a criação e o cumprimento dos contratos, as responsabilidades dos prestadores de serviços, os procedimentos de falência, a adjudicação de bens em liquidação e outras medidas contratuais. Mais importante, o código enumerou os tipos de papéis de crédito aceitos como meio de pagamento e padronizou seu formato para eliminar fraudes e aumentar sua aceitação pela população. ${ }^{6}$

4 Esta divisão seguiu a legislação da época. Os bancos S/A estrangeiros e os hipotecários ou universais foram assim denominados pela obrigação legal de obterem permissão especial do governo. No caso dos bancos hipotecários ou universais, esta permissão incluiu a autorização de emitir títulos especiais, as "letras hipotecárias". Os outros bancos S/A foram considerados bancos comerciais, que atuavam principalmente no mercado de crédito a curto prazo.

5 Brasil, Coleção de Leis e Decretos. Lei no 556, 25 de Junho de 1850. A partir de agora, referido como Leis e Decretos.

6 Leis e Decretos. Lei n ${ }^{\circ}$ 556, Parte I, Título XVI, p. 120-133. 
As regulamentações bancárias indiretas do Código Comercial foram mais cuidadosamente especificadas uma década mais tarde, num decreto publicado para regular a criação e a organização dos bancos. ${ }^{7}$ Qualquer companhia que procurasse prover serviços bancários requereria a autorização legislativa do governo imperial, processo que envolvia a participação ativa dos presidentes de província, ministros do governo e parlamentares, dificultando a sua obtenção. Os bancos poderiam realizar "quaisquer operações chamadas de Banco, ou que fomentem o desenvolvimento do crédito público", exceto a emissão de moeda. Isto incluía "empréstimos de qualquer espécie, ou natureza; operações de câmbio; depósitos de valores de qualquer natureza; [e] abertura de contas correntes". ${ }^{8}$ Todos os outros serviços bancários de curto e longo prazo, com exceção da emissão de quaisquer "notas, bilhetes, letras, vales, papéis ou títulos de qualquer natureza", foram permitidos por este decreto e realizados preferencialmente em termos gerais, que deixam muitas condições para a diferenciação entre os intermediários. ${ }^{9}$

O Código Comercial e as leis empresariais relacionadas permitiram a formação de bancos a partir de casa bancária, sociedade ou companhia por ações, dependendo da boa vontade dos financiadores em assumir risco e da submissão à supervisão do governo. ${ }^{10}$ Por conta das restrições e das condições das leis impostas para as sociedades anônimas, ao menos a metade dos bancos, operando na Província de São Paulo antes dos anos 1880, consistiu em organizações com um único proprietário ou sócio, conhecidas como casas bancárias. Estas últimas foram limitadas em tamanho pelo capital de seus fundadores, ao contrário das organizações anônimas, que ofereceram uma base substancialmente ampla de capital. Este ambiente conservador de regulação em que os primeiros bancos operaram ajudou a restringir o crédito na economia brasileira. Somente três bancos se formaram como sociedades anônimas na província antes de 1880 , sendo dois domésticos e um estrangeiro. ${ }^{11}$

7 Leis e Decretos. Decreto ${ }^{\circ}$ 2.711, de 19 de Dezembro de 1860. Este decreto "contém várias disposições sobre a criação e organização de bancos, companhias, sociedades anônimas e outras". A lei irmã, n ${ }^{\circ}$ 1.083, de 22 de Agosto de 1860, tornou-se conhecida como Lei dos Entraves, em virtude de restringir estas atividades.

8 Leis e Decretos. Ibidem, Artigo $1^{\circ}$. A Lei $n^{\circ}$ 1.083, de 22 de Agosto de 1860, regulou os bancos de emissão.

9 Ibidem.

10 Até 1882, todas as companhias formadas como sociedade anônima tinham de obter uma autorização do governo. Este processo burocrático limitou a formação das companhias em geral e, particularmente, dos bancos; Leis e Decretos. O Decreto $n^{\circ} 575$, de 10 de Janeiro de 1849, foi o primeiro a regular a formação de sociedades anônimas, incluindo o requerimento para a autorização do governo. O Decreto $n^{0} 2.457$, de 5 de Setembro de 1859, requer que todas as instituições bancárias enviem aos agentes fiscais do governo declarações financeiras semanais para o relatório governamental de ambas as esferas de governo - imperial e provincial — impondo multas elevadas para os que não o cumprissem. Por fim, a Lei n ${ }^{\circ} 1.083$, de 22 de Agosto de 1860, e o Decreto $\mathrm{n}^{\circ} 2.711$, de 19 de Dezembro de 1860, introduziram sanções, punindo empresários que levantassem seu capital por meio da venda de ações sem autorização do governo.

11 Hanley (2005, cap. 2). 
Mais importante, as primeiras leis bancárias e empresariais falharam em criar as salvaguardas necessárias para estimular os investimentos em créditos mais arriscados de longo prazo, como para a cafeicultura, em que o cafeeiro só produz a partir do quarto ano do plantio, e com garantias menos líquidas, como imóveis urbanos e rurais. A dificuldade de definição dos domínios da propriedade e a falta de publicidade e especialidade das garantias comprometiam o funcionamento do mercado de crédito hipotecário, diminuindo os recursos, onerando os juros e encurtando os prazos. ${ }^{12}$ A legislação até 1860 não impediu que os bancos fizessem empréstimos de maior prazo, mas não ofereceu incentivos para compensar banqueiros e seus investidores. Os legisladores imperiais procuraram retificar estes problemas e promover o crédito por meio de uma lei hipotecária, em 1864, que estabeleceu o registro hipotecário e procurou eliminar um dos impedimentos ao crédito de longo prazo: a necessidade de uma fonte de longo prazo de fundos bancários para emprestar. ${ }^{13}$ Esta lei e o decreto de 1875 permitiram aos bancos de crédito real, especificamente autorizados, emitir uma letra transferível, denominada "letra hipotecária", e que os recursos amealhados na venda fossem destinados aos empréstimos de sua carteira hipotecária. ${ }^{14}$ As letras podiam ser nominativas ou ao portador e transmissíveis por simples endosso e seriam resgatadas pelo método determinado pelo banco, geralmente por loteria sobre uma escala prévia, eliminando a vulnerabilidade bancária a mudanças súbitas do mercado hipotecário ou das condições econômicas fundamentais. ${ }^{15}$ Além de maior publicidade e especificidade para as hipotecas, facilitando a proteção dos créditos e incrementando o mercado, a lei hipotecária de 1864 possibilitou especificamente aos bancos uma fonte de prazos mais alongados de fundos destinados ao crédito hipotecário.

Mesmo com esta provisão de fundos de prazo adequado para o crédito hipotecário, poucos banqueiros no Brasil e nenhum em São Paulo formaram bancos hipotecários por quase duas décadas após a aprovação da lei de $1864 .{ }^{16} \mathrm{Um}$ dos argumentos levantados para a ineficácia da lei nesse sentido foi a dificuldade de aceitação das

12 Ver Jacomino (2006) para uma discussão da importância histórica do registro hipotecário para a publicidade da posse de imóvel, em detrimento do cadastro de terras originário da lei de terras de 1850

13 Leis e Decretos. Lei ${ }^{\circ}$ 1.237, de 24 de Setembro de 1864, e Regulamento $\mathrm{n}^{\circ}$ 3.453, de 26 de abril de 1865. A primeira criou o ônus real e a transcrição das hipotecas, mas o segundo ressalvou que a transcrição não era prova de domínio da propriedade.

14 Ver o Decreto $n^{\circ} 2.687$, de 6 de Novembro de 1875, que concedia garantia de juros de até 5\% ao banco de crédito real que se fundasse no Império, de acordo com a Lei de 1864. Este banco deveria emprestar à taxa de juros-limite de $7 \%$ e prazo de 5 a 30 anos.

15 Estes empréstimos poderiam ser realizados pelo prazo entre dez e trinta anos para até a metade do valor avaliado da propriedade rural, e até três quartos do valor avaliado da propriedade urbana. Uma parcela poderia ser resgatada pelo valor de face, em idêntico prazo, por uma loteria anual.

16 Antes da própria lei existiram bancos que deveriam se direcionar ao crédito rural, como o Banco Rural e Hipotecário e o Banco Comercial e Agrícola, sediados no Rio de Janeiro nas décadas de 1850 e de 1860. Entretanto, como salientou Carlos Gabriel Guimarães (2007), a carteira de descontos de hipotecas foi muito menor do que a comercial. 
letras que concorriam com as apólices públicas, que rendiam juros semelhantes e com risco menores. Ademais, Rui Barbosa também atribuiu tal empecilho à limitação dos juros. ${ }^{17}$ Verificamos alguns casos de empréstimos bancários por meio de hipotecas, nos anos 1860 e 1870, por bancos comerciais em São Paulo, mas a maioria era de valor pequeno. A Caixa Filial do Banco do Brasil da Província de São Paulo registrou, já em 1866, as suas duas primeiras hipotecas. Elas somaram apenas 25 contos de réis, quantia bastante inferior ao conjunto das operações de crédito do banco, que totalizou quase 2 mil contos. A partir desse ano, vários pequenos empréstimos ocorreram até 1875 , todos pela Caixa Filial. ${ }^{18}$ Não se registrou nenhuma hipoteca bancária nos anos posteriores à crise comercial e financeira desse último ano, que culminou com a falência do Banco Mauá \& Cia. ${ }^{19}$ A única exceção foi a principal hipoteca do período, realizada pelo Deutsche Brasilianische Bank, que efetuou apenas uma transação em 1878. Ele emprestou à Companhia Sorocabana 2.288 contos de réis, hipotecando A estrada de ferro da Companhia Sorocabana com todo o seu material, trem rodante, oficinas, estações, utensílios e tudo quanto à mesma pertence. Não há outro exemplo de hipoteca de tal importância nessas duas décadas, inexistindo banco dedicado ao crédito de longo prazo.

A ausência de banco legalmente denominado como "hipotecário" deveu-se, em parte, às dificuldades de execução das propriedades, de captação de recursos e à incerteza sobre a oferta de mão de obra, em virtude da abolição do tráfico de escravos, problemas que precisavam ser equacionados para viabilizar o boom do café no oeste paulista. Os procedimentos e as práticas de execução realizadas não nos parecem ter mudado no decorrer da segunda metade do século 19, mas o mercado de trabalho ampliou-se consideravelmente em meados dos anos 1880, como resultado

17 No governo republicano, Rui Barbosa colocava a lei de 1875 como uma das poucas do Império que se esforçaram para beneficiar a lavoura. Para o autor, o crédito hipotecário era um dos maiores elementos vitais para a agricultura e, em geral, para a expansão econômica das nossas forças (1891, p. 161). Entretanto, a lei ainda não resolveu a diferença entre o custo da captação e o da aplicação do recurso para o banco, citando o Visconde de Inhomirim, na época da aprovação da lei no Senado: Quanto a letras hipotecárias, a lei nada exige. Nem os bancos têm interesse algum em emiti-las; porque, sendo difícil a negociação de tais letras, eles não as poderiam negociar senão acima de 6\%, que é quanto recebem dos mutuários; e então seria preciso tirar a diferença do seu próprio lucro, e o negócio não se tornaria bom para eles (ibidem, p. 154). Ao final da década de 1870, ocorreram diversas discussões entre os parlamentares sobre a necessidade de modificar tal quadro para viabilizar a expansão do crédito, na maioria das vezes com o apoio do Estado, por meio de subsídios.

18 O Banco do Brasil deixou de aceitar os escravos como colateral das hipotecas em 1884. Tal ativo sempre foi considerado mais líquido do que as terras, facilitando a execução dos bens hipotecados. A perda desta possibilidade de garantia conduziu à necessidade de aceitar os outros bens para as transações. Na cidade de São Paulo, a presença dos escravos como garantia dos empréstimos foi bastante restrita, pois localizamos tão-somente 13 casos em cerca de mil hipotecas até 1880 . Assim, verificamos na capital paulista transações garantidas essencialmente por bens imóveis e suas benfeitorias, que foram amplamente aceitos pelos credores.

19 Esta retração não foi apenas na praça paulista. Como relata Théo Piñeiro (2007), o Banco do Brasil reduziu a importância da sua carteira hipotecária ao final da década de 1870 em razão das oportunidades surgidas de financiamento do Tesouro Nacional. 
do sucesso dos programas de promoção da imigração para substituir a mão de obra escrava, principalmente na Província de São Paulo, mas também com repercussão na capital paulista. ${ }^{20}$ A conclusão da transição para o trabalho livre e o movimento para capitalizar rapidamente a cafeicultura, em face da demanda externa crescente para o café, fizeram os cafeicultores buscar novos meios de acessar recursos. A demanda de crédito foi especialmente intensa em São Paulo, onde o aumento da produção de café se somou ao crescimento do mercado consumidor doméstico, alimentado pelo maior emprego da mão de obra livre, gerando uma expansão econômica forte, inclusive no meio urbano. Os banqueiros de São Paulo responderam a duas mudanças legislativas na década de 1880, uma nacional e outra no plano provincial, para expandir o crédito na província. ${ }^{21}$ No plano nacional, os legisladores imperiais eliminaram, com poucas exceções, o requerimento para empreendedores obterem a autorização governamental, a fim de instituírem uma sociedade anônima. Deste modo, somente os bancos estrangeiros, hipotecários e de emissão ainda necessitavam obter esta autorização governamental para se formarem por meio da venda de ações. ${ }^{22}$ Todos os outros bancos foram liberados para se organizar como sociedade anônima, simplesmente pelo registro na Junta Comercial dos seus estatutos e uma declaração de que levantaram $10 \%$ do seu capital. ${ }^{23}$ No plano da província, a Assembléia de São Paulo aprovou, em 1881, uma lei que ofereceu 6\% de garantia de lucros aos investidores de qualquer banco que atuasse como financiador hipotecário para a Província de São Paulo. ${ }^{24}$

A lei imperial de 1882 incluiu uma desagradável provisão, deixando potencialmente os investidores em sociedades anônimas com a responsabilidade ilimitada, porém o expressivo boom do café em São Paulo ultrapassou esta preocupação de investir em novos bancos e de comprar ações adicionais dos bancos existentes. ${ }^{25}$ Bancos

20 O deputado Dantas afirmou, com relação à escassez de capitais, em sessão da Câmara de 21 de Junho de 1877: Desde que a sua propriedade não tem cadastro e por outro lado onerada de obrigações e ônus, não pode servir de garantia para levantar a juro módico e com prazos longos, capitais que a desonerem de graves e pesados compromissos (...) (1877, p. 198).

21 Flavio Saes (1986) analisa a relação entre a expansão cafeeira e o crescimento do setor bancário.

22 Leis e Decretos. Lei no 3.150, de 4 de Novembro de 1882. Decreto no 8821, de 20 de Dezembro de 1882.

23 Leis e Decretos. Lei ${ }^{\circ}$ 3.150. Havia determinadas exigências públicas para a divulgação, tais como a exigência de que publicassem seus estatutos no jornal oficial de sua província, mas não foram mais requeridos a submeter ao governo, semanal ou mensalmente, relatórios financeiros e poderiam constituir-se com o depósito de uma parte menor do capital social (10\% em comparação a $25 \%$ em leis anteriores) e suas ações poderiam ser negociadas antes - as leis $\mathrm{n}^{\circ} 1.849$ e $\mathrm{n}^{\circ} 1.860$ de sociedade anônima requeriam que $25 \%$ do valor nominal fosse integralizado antes de negociar as ações, mas a lei de 1882 abaixou a exigência para 20\% do valor das ações.

24 Coleção de leis e posturas municipais promulgadas pela Assembléia Legislativa Provincial de São Paulo no Ano de 1881. Lei provincial n ${ }^{\circ}$ 145, de 25 de Junho de 1881. As garantias de lucro significavam que, se a companhia não atingisse um retorno de $6 \%$ do capital, o governo suplementaria o lucro líquido da companhia até alcançar 6\%. Em contrapartida, a companhia reembolsaria o governo pela quantia suplementada, quando sua taxa do lucro excedesse $6 \%$.

25 Leis e Decretos. Lei ${ }^{\circ}$ 3.150, de 4 de Novembro de 1882, Artigo $7^{\circ}$. 
estrangeiros continuaram a ser sujeitos ao requerimento de autorização governamental, mas eles igualmente não resistiram às possibilidades oferecidas pela economia cafeeira. No total, sete novos bancos comerciais formaram-se na Província de São Paulo nos anos 1880, quatro domésticos e três estrangeiros, elevando o total a dez bancos comerciais. ${ }^{26}$ A mudança da lei provincial, fornecendo garantias a bancos hipotecários, também alargou a disponibilidade de crédito na praça. A promulgação da lei provincial de 1881 incentivou a formação do Banco de Crédito Real de São Paulo, que ofereceu crédito de longo prazo, necessário para financiar a expansão da produção de café e das demais atividades relacionadas, até mesmo urbanas.

Em 1885, fortaleceu-se a importância do registro das hipotecas, tornando obrigatória a sua inscrição. ${ }^{27}$ De outro lado, durante o período denominado Encilhamento, a política executada produziu grande repercussão na economia, nas finanças e na balança de pagamentos. Num período de mudança institucional, com a abolição da escravatura e disseminação do trabalho livre, a flexibilidade da política monetária ocorreu, principalmente, por meio de novos bancos emissores, iniciada em 1888 e atingindo o seu ápice em 1892. A partir desse ano, começaram a se conter os excessos do período, porém a restrição mais forte da política monetária ocorreu a partir de $1898 .^{28}$

O governo provisório da República não apenas modificou a política econômica, como também procurou modificar a legislação acerca das hipotecas e dos imóveis. As mudanças legais de 1890 não modificaram de forma expressiva as leis em vigor, mas reforçaram as garantias das letras hipotecárias e a importância do registro, atualizando a forma deste registro e dos bens, objetos de hipoteca. ${ }^{29} \mathrm{Com}$ relação às garantias e aos domínios das propriedades, a principal mudança desse momento foi a tentativa da implementação do sistema Torrens no Brasil, a partir do Decreto no 451-B, de Maio de 1890, de forma facultativa aos proprietários. Rui Barbosa buscou fornecer aos títulos de domínio plena segurança, por meio da publicidade ampla,

26 Os bancos domésticos e seus respectivos anos de fundação foram: Banco Comercial (1886), Banco da Lavoura (1886), Banco Popular (1888) e Banco de São Paulo (1889). Os bancos estrangeiros e seus anos de criação foram os seguintes: London and Brazilian Bank Ltd., fundado em Santos (1881), English Bank of Rio de Janeiro-São Paulo (1882) e Brasilianische Bank für Deutschland, fundado em São Paulo (1888). Apesar de este último banco ter sido criado em 1888, não apresentou informação para 1889 .

27 Os parlamentares procuraram diminuir as incertezas a respeito de execuções com o Decreto ${ }^{0}$ 3.272, de 5 de Outubro de 1885, mas, conforme Triner (2000), estas incertezas continuavam a dificultar a consolidação do mercado hipotecário pelo menos até a virada do século 20. Este decreto obrigou a inscrição das hipotecas e aprimorou a execução das dívidas.

28 Ver Franco (1983 e 1990) e Schulz (1996).

29 O Decreto $n^{\circ}$ 169-A, de 19 de Janeiro de 1890, mencionou explicitamente a hipoteca de engenhos centrais, fábricas, usinas, oficinas e ferrovias, abrangendo edifícios e maquinismos. O Decreto $\mathrm{n}^{\circ} 370$, de 2 de Maio de 1890, elevou os juros ao máximo de $8 \%$, facilitando o levantamento de recursos. Por fim, o Decreto ${ }^{\circ}$ 612, de 3 de Julho de 1890, concedeu a criação do Banco Hipotecário Nacional. 
da mobilização da propriedade por simples endosso e do aval de boa origem. ${ }^{30}$ Destarte, tal política tentava minorar os conflitos de terras e facilitar o crédito mediante os títulos de absoluta validade e eficácia, mas de aplicação bastante difícil nas condições do país naquele momento. De fato, no século 20, a sua aplicação restringiu-se aos imóveis rurais de alguns Estados.

A nossa pesquisa nos balanços contábeis possibilita observar uma visão geral das transformações do crédito. O efeito destas novas instituições bancárias sobre o financiamento em São Paulo foi dramático. Os quatro bancos operando em 1882, incluindo um estrangeiro, formado recentemente, emprestaram um total de 14,5 mil contos de réis ao mercado paulistano. ${ }^{31} \mathrm{Em}$ 1886, com sete bancos comerciais em operação, o valor do crédito de curto prazo cresceu em quase $40 \%$, atingindo 20,2 mil contos. Até o final da década, os bancos comerciais tinham mais de 22 mil contos em empréstimos para sua clientela. A criação do Banco de Crédito Real diversificou substancialmente o crédito, alcançando mais de 5 mil contos em hipotecas, em 1886, quantia esta que quase dobrou até $1889 .{ }^{32}$ Neste total, o crédito distribuído por bancos S/A em São Paulo cresceu de 14,5 mil para 31,8 mil contos, ao longo da década. Na década de 1880, as mudanças legais e o estabelecimento do Banco de Crédito Real de São Paulo conduziram a um incremento dos financiamentos bancários. Assim, durante a década de 1880, estabeleceu-se um mercado mais ativo de hipotecas bancárias.

\section{Bancos na Transição Republicana}

A proclamação da República produziu uma série de reformas legais que impulsionaram as empresas e o mercado de crédito. ${ }^{33}$ Estas reformas estimularam uma expansão significativa das instituições do setor bancário em São Paulo, que ocorreu, primeiramente, por meio da formação de novos bancos comerciais, mas também incluiu a formação de duas novas instituições de crédito de longo prazo e dois novos bancos estrangeiros. A primeira reforma introduziu responsabilidade limitada para os acionistas das sociedades anônimas, derrubando finalmente esta barreira à formação de instituições bancárias. ${ }^{34}$ Dezenas de novos bancos domésticos beneficiaram-

30 Em seu relatório, o Ministério da Fazenda esclarece: estabelecer um sistema eficaz de publicidade imobiliária e comercializar a circulação dos títulos relativos ao domínio sobre a terra (BARBOSA, op. cit., p. 188).

31 Um conto de réis é um milhão de réis.

32 O Banco de Crédito Real detinha mais de 9,5 mil contos de réis em empréstimos hipotecários até o final de 1889.

33 As reformas principais foram realizadas pelos Decretos $n^{\circ} 162$, de 17 de Janeiro de 1890, ${ }^{\circ} 165$, de 17 de Janeiro de 1890, e $\mathrm{n}^{\circ} 169-\mathrm{A}$, de 19 de Janeiro de 1890. Leis e Decretos.

34 A reforma de janeiro de 1890 incrementou a formação de empresas de todos os tipos, abaixando as exigências de capital para operar e negociar ações, virtualmente eliminando a responsabilida- 
se desta mudança institucional nos anos seguintes à reforma de 1890, provocando um acréscimo acima de três vezes no crédito bancário de 1889 para 1901. Muitos dos novos bancos faliram ao final do Encilhamento, mas, como Flávio Saes mostrou, há uma resistência significativa de muitos bancos e a formação de novas instituições bancárias após o Encilhamento. ${ }^{35}$ Os balanços contábeis das instituições que sobreviveram à euforia inicial e subseqüente recessão dos anos 1890 mostram uma clara e dramática expansão do crédito de curto prazo no início da década para o Estado de São Paulo, seguida por uma sustentada elevação do valor total deste crédito, como visto na Tabela 1. A estabilização dos valores totais do crédito bancário ocorreu a partir de 1892.

Tabela 1 - Empréstimos na Província ou Estado de São Paulo (em mil contos de réis e valores nominais)

\begin{tabular}{lrrrrrr}
\hline Tipos de instituição bancária & 1886 & 1889 & 1890 & 1892 & 1895 & 1901 \\
\hline Número & 8 & 10 & 9 & 15 & 16 & 18 \\
Bancos comerciais brasileiros & & & & & & \\
na capital & 14,9 & 12,9 & 38,6 & 65,7 & 62,9 & 56,6 \\
no interior & & & & 6,6 & 8,9 & 13,2 \\
Bancos estrangeiros & 5,2 & 9,4 & 6,4 & 6,4 & 12,0 & 26,6 \\
Bancos universais: carteira comercial & - & - & 20,5 & 16,5 & 13,1 & 3,4 \\
Bancos universais: carteira hipotecária & 5,6 & 9,5 & 11,8 & 26,9 & 24,1 & 27,0 \\
& & & & & & 121,0 \\
Total do crédito bancário & 25,7 & 31,8 & 77,3 & 122,1 & 126,8 \\
\hline
\end{tabular}

Obs: Os balanços contábeis dos bancos universais separam a carteira comercial da hipotecária. A relação dos bancos incluídos nesta tabela encontra-se no anexo.

A segunda reforma introduziu os bancos universais, com amplo direito de atuar como instituição de múltiplas funções de crédito, para estimular o desenvolvimento econômico. ${ }^{36}$ Estes bancos foram autorizados a executar uma variedade de serviços que incluíram atividades de crédito comercial, como por exemplo, a provisão de empréstimos de curto prazo, descontos e câmbio; as atividades de crédito agrícola e a hipotecária, como a provisão de financiamentos de longo prazo, garantidos por propriedades imobiliárias rurais ou urbanas, e adiantamentos contra colheitas futuras; crédito industrial para a construção de prédios, ferrovias, docas, melhorias

de do acionista além do valor de suas próprias ações. Leis e Decretos. Decreto n ${ }^{\circ} 164$, de 17 de Janeiro de 1890.

35 Ver Saes (op. cit., p. 95-100).

36 Estes direitos foram inicialmente garantidos aos bancos de emissão, via Decreto $\mathrm{n}^{\circ} 165$, de 17 de Janeiro de 1890, e estendidos a todos os bancos hipotecários dois dias depois, via Decreto $\mathrm{n}^{\circ}$ 169-A, de 19 de Janeiro de 1890. Leis e Decretos. 
portuárias, comunicações e atividades administrativas, como a propriedade e a operação de interesses industriais. ${ }^{37}$

Três bancos universais funcionaram em São Paulo como resultado desta nova lei. O existente Banco de Crédito Real manteve a carteira hipotecária, diversificando-se na área comercial, com a aquisição do Banco Comercial de São Paulo (um dos novos bancos criados na década de 1880), e desfrutando de fundos governamentais em uma terceira carteira destinada a um tipo específico de crédito hipotecário agrícola. O novo Banco União de São Paulo teve um formato mais complexo, pois atuou tanto como banco de emissão de São Paulo quanto hipotecário e comercial. No entanto, a sua vida como banco de emissão foi breve e ele consistentemente dedicou a maioria dos seus recursos a hipotecas urbanas e a desenvolvimento de negócios industriais. ${ }^{38}$ Por fim, o último banco universal foi o Banco de Santos, que apresentou uma participação mais modesta no mercado hipotecário, possuindo quase todos os seus ativos na carteira comercial. As duas primeiras instituições universais foram as maiores participantes no mercado hipotecário de São Paulo, realizando também uma contribuição substancial para o mercado de crédito comercial.

Os dados da Tabela 1 mostram as participações relativas no mercado dos diferentes tipos de bancos que operaram em São Paulo, de acordo com sua forma institucional. Os bancos comerciais da capital e do interior mantiveram a maior parcela dos empréstimos, variando entre 50\% (1890) e 59,3\% (1895), em todos os anos, com exceção de 1889, quando realizaram 40,6\% dos empréstimos. Os universais alcançaram uma participação maior no mercado financeiro em 1890 (41,8\%) e em 1892 $(35,5 \%)$, reduzindo-a posteriormente - 24,0\% em 1901. De outro lado, os estrangeiros retraíram-se nesses primeiros anos da década de 1890, perfazendo somente 8,3\% e 5,3\% dos empréstimos. Contudo, no último ano em análise na Tabela 1, os bancos estrangeiros representaram $21,0 \%$ do mercado bancário, rivalizando com os comerciais brasileiros. Deste modo, durante a década de 1890, verificamos retração dos universais e avanço dos estrangeiros, principalmente no final do período.

Como somente os bancos de crédito real detinham o direito de emitir letras hipotecárias — os instrumentos que levantavam capital de longo prazo para aplicar em empréstimos hipotecários de maior prazo — poderíamos pensar que os bancos comerciais não entrariam neste mercado. O estudo dos balanços contábeis oferece poucas pistas para a complexidade de suas operações bancárias, portanto, poucas

37 Estes bancos apreciaram os privilégios e as isenções expressivas, atuando como incentivos para se engajarem nestes projetos de desenvolvimento, mas também tiveram que se comprometer a uma série de condições do governo republicano para assegurar suas boas intenções. Para uma discussão mais detalhada das leis e dos regulamentos para estes bancos e seu comportamento na economia de São Paulo, ver Hanley (op.cit., cap. 5)

38 O Banco União de São Paulo é o predecessor do gigante conglomerado Votorantim. Ele deixou a atividade bancária em 1906 para centrar inteiramente seus negócios na indústria. 
informações para apoiar ou desmentir esta possibilidade. Estes documentos listam suas operações de crédito em contas muito pouco descriminadas, mais comumente como "letras descontadas" e "empréstimos em conta corrente". Ocasionalmente, um banco se distinguiu entre financiamento de curto e longo prazo, listando estas operações de crédito como "hipotecas urbanas" ou "empréstimos sob penhor", mas, ausentes estes termos, não há meio de conhecer, pelos balanços contábeis, se os bancos comerciais ofereceram crédito a longo prazo, como o hipotecário. Por sua vez, bancos estrangeiros eram normalmente proibidos pelo escritório da matriz de realizar empréstimos hipotecários. A preocupação da matriz com a liquidez revelou-se em comunicados aos escritórios das filiais, advertindo contra qualquer empréstimo que não se liquidasse com facilidade. ${ }^{39}$

A nossa pesquisa nos registros cartorários paulistanos de hipotecas permite aprofundar o entendimento das práticas de empréstimos de cada instituição bancária. ${ }^{40}$ Esta pesquisa nos registros hipotecários demonstra que, de fato, a maioria das hipotecas registradas pelos bancos domésticos foi realizada pelos dois maiores bancos hipotecários: Banco de Crédito Real e Banco União de São Paulo. Como observado na Tabela 2, estes dois bancos contabilizaram, em conjunto, quase a metade do número de empréstimos. No entanto, vários bancos comerciais paulistas também efetuaram estes registros, salientando que a ausência de fundos de longo prazo não foi uma barreira para o empréstimo hipotecário. Ademais, os bancos estrangeiros de São Paulo também ignoraram o conselho do escritório da matriz e entraram no mercado hipotecário. Muitas vezes, a busca por melhores garantias aos seus empréstimos conduziu os bancos não especializados a realizarem hipotecas.

Fornecemos, na Tabela 2, a participação dos bancos no mercado hipotecário paulistano de 1888 a 1901. Coletamos todas as hipotecas de bancos registrados no $1^{\circ}$ Cartório da cidade de São Paulo no período, que totalizaram 405 casos. Não obstante o número reduzido de transações, notamos um papel expressivo dos estrangeiros entre as instituições bancárias, representando quase a metade dos valores transacionados pelos bancos no período. Tal resultado derivou de um financiamento extraordinário, de fato um lançamento de títulos preferenciais, realizado para a Companhia Paulista de Vias Férreas e Fluviais, em 1892, intermediado pelo British Bank of South América. ${ }^{41}$ Tal operação atingiu 2.750 mil libras esterlinas e repre-

39 David Joslin, em sua história do banco britânico Bank of London \& South America Limited, ressaltou que as correspondências entre o escritório da matriz e os das filiais estrangeiras advertiram contra qualquer empréstimo que não se liquidasse (1963, p. 152-173).

$40 \mathrm{Um}$ primeiro resultado desta pesquisa pode ser observado em Marcondes e Maduro Júnior (2005). Tal pesquisa contou com o apoio do CNPq, durante os anos de 2004 a 2006. Atualmente, a pesquisa conta com apoio da Fapesp, denominada Crédito Hipotecário em São Paulo: Séries Históricas (1865-1914).

41 As atividades bancárias desta instituição começaram em 1862, como Brazilian and Portuguese Bank, e, em 1866, se alteraram para English Bank of Rio de Janeiro. Em 1891, o nome do banco 
sentou pouco mais de um terço dos valores totais hipotecados. Foi garantida pelas linhas da estrada de ferro e de navegação fluvial que já pertenciam à companhia devedora antes da negociação feita, com todos os seus materiais e edifícios e estradas em diversas comarcas. As condições do empréstimo mostraram-se muito superiores ao comumente efetuado na praça paulistana, em virtude de uma taxa de juros cobrada de $5 \%$ ao ano e um prazo de 42 anos. Consideramos tal hipoteca de forma isolada, a fim de evitar distorções dos nossos resultados.

Outro caso semelhante a esse ocorreu em 1901, entre a Companhia The São Paulo Tramway Light and Power, financiada pelo banco National Trust Company Limited, ambos oriundos do Canadá. A empresa iniciou suas atividades em 1899, com a construção da Usina Hidrelétrica Parnaíba. Os imóveis hipotecados referem-se principalmente a terrenos e equipamentos relacionados à geração e à distribuição de energia elétrica. O total do empréstimo alcançou seis milhões de dólares canadenses, com vencimento em $1^{\circ}$ de junho de 1929 , a uma taxa de juros de $5 \%$ ao ano.

Os demais financiamentos de bancos estrangeiros totalizaram um pequeno número de transações — trinta e um — mas de porte mais expressivo do que o mais comum das hipotecas, atingindo em média quase 200 contos de réis. Desconsiderando os dois casos citados acima, os estrangeiros foram responsáveis por pouco mais de um décimo dos valores transacionados (13,5\%). As taxas de juros mostraram-se próximas do normalmente efetuado nesse mercado, atingindo em média 8,1\% ao ano, enquanto os prazos revelaram-se superiores, pouco mais de quatro anos.

Não apenas os estrangeiros atuaram no mercado hipotecário paulistano, os bancos nacionais sediados no Rio de Janeiro também operaram valores expressivos na praça paulistana. ${ }^{42}$ Entre essas instituições, as universais - o Banco da República do Brasil e o Banco de Crédito Real do Brasil - e o Banco do Brasil (RJ) destacaramse, compreendendo quase a totalidade das transações e, principalmente, dos valores negociados pelos bancos sediados na capital do país. Apesar de realizarem pouco menos de 5\% das hipotecas - 22 - perfizeram pouco mais de quatro décimos dos valores hipotecados pelos bancos $(39,8 \%)$. O valor médio das hipotecas revelou-se bastante superior ao dos estrangeiros, chegando a 1.400 contos de réis. Os prazos das hipotecas foram muito elevados — média de quase 12 anos - e as taxas de juros, reduzidas - 6,7\% ao ano, em média. Devemos lembrar que a capital brasileira consistia na sede dos principais bancos nacionais. Deste modo, a praça paulistana atraiu recursos consideráveis de outras praças brasileiras por meio de instituições bancárias nacionais.

foi alterado para conduzir as operações no Brasil e na Argentina.

42 Trata-se do Banco de São Paulo e Rio de Janeiro, Banco do Brasil - Rio de Janeiro, Banco de Crédito Real do Brasil e Banco República do Brasil. 
Tabela 2 - Hipotecas por Bancos em São Paulo de 1888 a 1901 (em valores nominais)

\begin{tabular}{|c|c|c|c|c|c|}
\hline Instituição & $\mathrm{N}^{\circ}$ & $\begin{array}{l}\text { Valor total } \\
\text { emprestado }\end{array}$ & $\%$ Total & $\begin{array}{l}\text { Prazo médio } \\
\text { (meses) }\end{array}$ & $\begin{array}{l}\text { Taxa de juros } \\
\text { média anual }\end{array}$ \\
\hline \multicolumn{6}{|l|}{ Bancos comerciais } \\
\hline Banco Colonial & 1 & $1: 525 \$ 400$ & 0,0 & 8 & $12,00 \%$ \\
\hline Banco Comercial da Bolsa de São Paulo & 4 & $32: 000 \$ 000$ & 0,0 & 14 & $10,50 \%$ \\
\hline Banco Comercial Paulista & 7 & $76: 006 \$ 000$ & 0,1 & 15 & $10,00 \%$ \\
\hline Banco da Lavoura & 12 & $478: 000 \$ 000$ & 0,6 & 12 & $9,75 \%$ \\
\hline Banco de Melhoramentos de São Paulo & 3 & $3.624: 400 \$ 000$ & 4,6 & 88 & $7,33 \%$ \\
\hline Banco de Piracicaba & 3 & 463:076\$700 & 0,6 & 17 & $13,33 \%$ \\
\hline Banco de São Paulo & 19 & $1.500: 604 \$ 840$ & 1,9 & 15 & $11,00 \%$ \\
\hline Banco de São Paulo e Rio de Janeiro & 3 & $657: 075 \$ 960$ & 0,8 & 14 & $10,50 \%$ \\
\hline Banco do Brasil - São Paulo ${ }^{1}$ & 25 & $973: 848 \$ 488$ & 1,2 & 77 & $6,67 \%$ \\
\hline Banco do Brasil - Rio de Janeiro & 4 & $3.050: 000 \$ 000$ & 3,9 & 140 & $6,50 \%$ \\
\hline Banco do Comércio e Indústria de São Paulo & 22 & 4.112:918\$890 & 5,2 & 14 & $8,95 \%$ \\
\hline Banco dos Lavradores ${ }^{2}$ & 24 & $1: 353: 924 \$ 600$ & 1,7 & 13 & $10,62 \%$ \\
\hline Banco Mercantil de Santos & 12 & $1.556: 481 \$ 340$ & 2,0 & 13 & $11,25 \%$ \\
\hline Casa Bancária Dumont \& Companhia & 3 & $420: 000 \$ 000$ & 0,5 & 7 & $11,33 \%$ \\
\hline Outros ${ }^{3}$ & 15 & $600: 856 \$ 277$ & 0,7 & 27 & $10,50 \%$ \\
\hline \multicolumn{6}{|l|}{ Bancos estrangeiros } \\
\hline Banque Française du Brésil & 5 & $2.192: 049 \$ 565$ & 2,8 & 10 & $9,20 \%$ \\
\hline Banque Belge de Préts Fonciers & 9 & $1.569: 727 \$ 013$ & 2,0 & 102 & $8,00 \%$ \\
\hline Brasilianische Bank für Deutschland & 2 & $1.834: 013 \$ 028$ & 2,3 & 25 & $12,00 \%$ \\
\hline $\begin{array}{l}\text { British Bank of South America Limited / } \\
\text { English Bank of Rio de Janeiro }\end{array}$ & 3 & $2.793: 773 \$ 829$ & 3,5 & 384 & $6,00 \%$ \\
\hline London and Brazilian Bank Limited & 10 & $1.933: 665 \$ 336$ & 2,4 & 20 & $8,50 \%$ \\
\hline Outros ${ }^{4}$ & 2 & $329: 278 \$ 350$ & 0,4 & 21 & $5,00 \%$ \\
\hline \multicolumn{6}{|l|}{ Bancos universais ou hipotecários } \\
\hline Banco de Crédito Real de São Paulo & 85 & $9.996: 465 \$ 770$ & 12,7 & 137 & $7,08 \%$ \\
\hline Banco de Crédito Real do Brasil & 5 & $4.758: 307 \$ 050$ & 6,0 & 192 & $6,50 \%$ \\
\hline Banco Hipotecário do Brasil e de São Paulo 5 & 3 & $300: 000 \$ 000$ & 0,4 & 165 & $8,67 \%$ \\
\hline Banco República do Brasil & 10 & $23.460: 124 \$ 390$ & 29,7 & 95 & $6,72 \%$ \\
\hline Banco União de São Paulo & 112 & $10.950: 757 \$ 600$ & 13,9 & 101 & $7,22 \%$ \\
\hline Subtotal & 403 & $79.018: 880 \$ 426$ & 100,0 & 79 & $8,15 \%$ \\
\hline \multirow{3}{*}{$\begin{array}{l}\text { Companhia Paulista / British Bank } \\
\text { São Paulo Tramway Light and Power/ Na- } \\
\text { tional Trust Company Limited } \\
\text { Total }\end{array}$} & 1 & $56.170: 212 \$ 765$ & 34,3 & 504 & $5,00 \%$ \\
\hline & 1 & $28.770: 000 \$ 000$ & 17,6 & 334 & $5,00 \%$ \\
\hline & 405 & 163.959:093\$191 & 100,0 & 81 & $8,13 \%$ \\
\hline
\end{tabular}

Obs: 1 Incluímos o Banco Construtor e Agrícola de São Paulo, que sucedeu à Caixa Filial do Banco do Brasil.

2 Incluímos o Banco Popular de São Paulo e o Banco Provincial de São Paulo, que antecederam o Banco dos Lavradores.

3 Incluímos os seguintes bancos comerciais domésticos: Banco de Santos, Banco Popular de Guaratinguetá, Banco da Lavoura e do Comércio do Brasil, Banco de Crédito Móvel de São Paulo, Banco do Estado, Banco Ítalo-Brasileiro, Banco Itália Brasile, Banco Operário, Banco Predial de São Paulo, Banco União de São Carlos e Banco Auxiliar do Comércio.

4 Incluímos o Banque d'Anvers e o London and River Plate Bank.

5 Reunimos dois casos do Banco Hipotecário do Brasil e um do Banco Hipotecário de São Paulo. 
Os bancos paulistas, tanto comerciais quanto universais, realizaram a grande maioria das transações, atingindo quase nove décimos do número de hipotecas. De outro lado, o valor integral financiado por esses bancos atingiu quase a metade do total (46,7\%). Como salientado antes, o Banco de Crédito Real de São Paulo e o Banco União de São Paulo foram os principais em número de transações e nos valores financiados. No conjunto dos paulistas, os empréstimos ocorreram, geralmente, em menores quantias, porém a prazos e juros próximos aos médios de todas as hipotecas - pouco mais de seis anos e 8,2\% ao ano. O valor médio das transações destes bancos alcançou tão-somente 105 contos de réis, menos de um décimo do verificado nos bancos nacionais e quase a metade nos bancos estrangeiros. ${ }^{43}$ A facilidade de acesso aos clientes e às suas informações favoreceram os bancos de São Paulo na concessão do crédito, permitindo alcançar valores mais reduzidos dos empréstimos e um contingente maior da população. Instituições menores participaram de forma esporádica ou até mesmo com certa regularidade ao longo do período, inclusive as do interior do Estado, como de Piracicaba, São Carlos e Guaratinguetá.

Dividimos os bancos em três grupos razoavelmente bem delimitados: comerciais, estrangeiros e universais ou hipotecários. Os primeiros totalizaram quase quatro décimos do montante de hipotecas registradas em São Paulo, porém perfizeram 23,9\% dos valores transacionados. Os bancos comerciais realizaram, em média, empréstimos de 120 contos. Todavia, a heterogeneidade deste grupo favoreceu a participação de alguns em situação mais próxima aos universais ou hipotecários, como o Banco do Brasil e o Banco de Melhoramentos de São Paulo, envolvendo, assim, montantes mais expressivos. Tal diferenciação do grupo refletiu-se também nos juros menores e nos prazos maiores destes últimos. Podemos ilustrar o restante do grupo por meio dos mais frequentes: Banco do Comércio e Indústria de São Paulo, da Lavoura, dos Lavradores, de São Paulo e Mercantil de Santos. Nestes casos, a taxa de juros manteve-se, em média, de 9\% a 11\% ao ano, e o prazo médio, ao redor de um ano. Por fim, alguns destes bancos mantinham hipotecas de valores bastante reduzidos, como o Banco dos Lavradores, que realizou a metade das suas transações com quantias inferiores a dez contos de réis. ${ }^{44}$

Os bancos estrangeiros já referidos acima também detinham um espectro bastante variado de aplicações no mercado hipotecário paulistano. Não obstante a existência de valores expressivos em condição de empréstimo mais longa (como o British e o English Bank), dois bancos estrangeiros aproximaram-se do perfil mais comum do grupo comercial: Banque Française du Brésil e London and Brazilian Bank Limited.

43 Até mesmo os bancos hipotecários mais atuantes mantiveram médias próximas deste valor.

44 O menor empréstimo foi de 600 mil réis em 1888, compreendendo a hipoteca de uma casa com 1 porta e 2 janelas de frente, em terreno de 10 metros de frente por 100 metros de fundo, na Vila Mariana. Devemos lembrar que a delimitação métrica dos terrenos tornou-se mais frequente apenas nesta década, salientando o avanço da especificidade das hipotecas. 
À exceção apenas dos valores praticados, bem maiores do que os dos bancos comerciais, as condições revelaram-se assemelhadas, como observado na Tabela 2.

O terceiro grupo reuniu as instituições universais ou especializadas em hipotecas, que efetuaram pouco mais da metade dos financiamentos - 53,4\% do total. O valor médio de suas operações chegou a 230 contos de réis, bastante superior ao dos comerciais. Como esperado, verificamos taxas de juros menores - 7,1\% - e prazos maiores - pouco mais de nove anos - do que os do primeiro grupo. O Banco de Crédito Real e o União de São Paulo consistiram nas instituições mais atuantes, realizando mais de nove décimos das transações do grupo.

Podemos buscar melhor entendimento das condições do financiamento bancário no mercado hipotecário verificando as relações entre valores, juros e prazos. No conjunto das hipotecas analisadas, observamos também a correlação de Pearson negativa entre prazo e taxa de juros dos empréstimos, estimada em $0,53 .{ }^{45}$ Quanto maior o prazo, há uma tendência de reduzir os juros dos financiamentos. Por outro lado, o valor não revelou uma correlação significativa com os juros ou com o prazo. Esse primeiro resultado não demonstrou uma clara relação dos valores com o prazo ou os juros.

Ao que tudo indica, as condições dos empréstimos (valor, prazo e juros) deveriam relacionar-se às características do devedor e das garantias e ao tipo de banco. Procuramos testar estas relações por meio de variáveis construídas a partir dos informes do devedor, do colateral e do banco. A grande maioria dos devedores foi registrada como proprietário $(60,5 \%$ do total), dificultando a caracterização das suas profissões. ${ }^{46}$ Uma tentativa de extrair informação do devedor foi a separação entre pessoas físicas e jurídicas. As companhias destacavam-se dos demais devedores de modo razoavelmente claro. Assim, utilizaremos esta variável — companhia — para explicar as condições.

Com relação às garantias, os imóveis hipotecados consistiram principalmente em casas/prédios e seus terrenos $(55,8 \%)$, terrenos sem construção $(22,1 \%)$, sítios e chácaras $(11,2 \%)$, oficinas e fábricas $(5,2 \%)$, olarias $(1,7 \%)$, fazendas $(1,5 \%)$ e armazéns $(1,7 \%)$. A diversidade dos tipos de colateral dificultou a sua caracterização, porém demonstra, no seu conjunto, o caráter urbano da capital e a importância deste setor imobiliário para as hipotecas. ${ }^{47}$ Possivelmente, os recursos levantados por meio das hipotecas destinaram-se a estes setores econômicos mais urbanos de uma cidade em

45 Nestes cômputos, continuamos a desconsiderar as duas grandes hipotecas da Companhia Paulista e da Light, em razão do caráter excepcional delas.

46 Os demais devedores detinham profissões diversas, especialmente de negociantes, lavradores/ fazendeiros e companhia.

47 Ver Lerias (op. cit.). 
grande expansão naquele momento. Quando consideramos o tipo de garantia, a distinção revelou-se bastante expressiva, pois as casas asseguraram empréstimos cerca de quatro décimos maiores, em média, do que os terrenos. Apesar desta diferença nos valores, as taxas de juros e os prazos de casas e terrenos não foram, em média, nem um décimo distintos. ${ }^{48}$ Tentaremos testar se o tipo do colateral poderia alterar as condições dos empréstimos, por meio de variáveis binárias, particularmente de ser terreno ou não. ${ }^{49}$

Se considerarmos os tipos de bancos em separado, o valor continua a não se correlacionar com os juros e o prazo para os bancos hipotecários. Ademais, estas instituições ainda mantinham correlação significativa entre juros e prazo, porém em menor intensidade: 0,33. As condições dos empréstimos não guardavam relações fortes entre si, à exceção de prazo e juros. Os bancos comerciais domésticos apresentaram resultados diferentes, havendo relação significativa não apenas entre prazo e juros, mas também entre valor e prazo. Por fim, os bancos estrangeiros não revelaram correlações significativas em nenhum dos casos analisados, talvez o reduzido número de observações tenha prejudicado este último resultado.

Podemos introduzir duas novas variáveis em nossos testes, referentes aos bancos hipotecários e estrangeiros, avaliando a importância destes dois tipos de banco para explicar as condições dos empréstimos em relação ao de referência, ou seja, o comercial doméstico. A partir destas variáveis construídas para devedor, garantia e banco, realizamos duas regressões para cada uma das condições dos empréstimos: uma, num formato mais amplo de variáveis, e outra, com as estatisticamente significativas. Podemos sumarizar os resultados alcançados nas regressões da Tabela 3.

Apesar das várias variáveis testadas, o valor foi explicado somente pela taxa de juros e pela presença de companhia, que aumentaram expressivamente os valores das transações. A dificuldade de determinar o valor pode ser mensurada mediante o coeficiente de determinação $\left(\mathrm{R}^{2}\right)$, que se mostrou bastante reduzido. Os juros revelaram uma influência de um conjunto maior de variáveis, apresentando um coeficiente mais expressivo. Além do prazo e do valor, banco hipotecário e estrangeiro explicaram as taxas de juros, aquelas, com sinais negativos e estas, positivos. Por fim, o prazo apresentou um conjunto de variáveis explicativas, semelhantes à da condição anterior, mas um pouco mais restritas, compreendendo os juros e os dois tipos de bancos. Isto revelou novamente a proximidade destas duas variáveis, à exceção do

48 No geral, a variância dos valores mostrou-se muito mais elevada do que a do prazo e dos juros, analisando-se por meio do coeficiente de variação.

49 Criamos variáveis para a presença de casa, terreno ou fábrica na garantia. Das diversas opções testadas, apenas a do terreno mostrou-se significativamente correlacionada com as condições de financiamento. Infelizmente, não dispomos da informação do valor do colateral, que poderia explicitar as formas de concessão do crédito dos bancos. 
valor a explicar os juros. Apesar do menor número de explicativas, a regressão do prazo forneceu o melhor coeficiente de determinação das três testadas.

\section{Tabela 3 - Determinantes das Condições de Financiamento}

\begin{tabular}{|c|c|c|c|c|c|c|}
\hline Variáveis Explicativas & Valor I & Valor II & Juros I & Juros II & Prazo I & Prazo II \\
\hline Constante & $\begin{array}{r}302668963 \\
(0,370)\end{array}$ & $\begin{array}{r}302462999^{*} \\
(0,010)\end{array}$ & $\begin{array}{l}12,08^{*} \\
(0,000)\end{array}$ & $\begin{array}{l}11,20^{*} \\
(0,000)\end{array}$ & $\begin{array}{r}127,58^{*} \\
(0,000)\end{array}$ & $\begin{array}{r}116,90^{*} \\
(0,000)\end{array}$ \\
\hline Taxa de Juros & $\begin{array}{r}-30683353^{*} \\
(0,086)\end{array}$ & $\begin{array}{r}-30395020^{*} \\
(0,026)\end{array}$ & - & - & $\begin{array}{l}-6,696^{*} \\
(0,000)\end{array}$ & $\begin{array}{r}-7,04^{*} \\
(0,000)\end{array}$ \\
\hline Prazo & $\begin{array}{l}662194 \\
(0,435)\end{array}$ & - & $\begin{array}{c}-0,02^{*} \\
(0,000)\end{array}$ & $\begin{array}{c}-0,02^{*} \\
(0,000)\end{array}$ & - & - \\
\hline Valor & - & - & $\begin{array}{r}0,00^{*} \\
(0,086)\end{array}$ & $\begin{array}{r}-0,00^{*} \\
(0,053)\end{array}$ & $\begin{array}{r}0,00 \\
(0,435)\end{array}$ & - \\
\hline Companhia & $\begin{array}{r}563603974^{*} \\
(0,000)\end{array}$ & $\begin{array}{r}604463412^{*} \\
(0,000)\end{array}$ & $\begin{array}{r}0,06 \\
(0,874)\end{array}$ & - & $\begin{array}{r}8,33 \\
(0,294)\end{array}$ & - \\
\hline Terreno & $\begin{array}{r}-247361 \\
(0,998)\end{array}$ & - & $\begin{array}{r}-0,07 \\
(0,806)\end{array}$ & - & $\begin{array}{r}-3,77 \\
(0,535)\end{array}$ & - \\
\hline Banco Hipotecário & $\begin{array}{r}46977092 \\
(0,664)\end{array}$ & - & $\begin{array}{c}-0,81^{*} \\
(0,015)\end{array}$ & $\begin{array}{l}-0,915^{\star} \\
(0,004)\end{array}$ & $\begin{array}{l}56,30^{*} \\
(0,000)\end{array}$ & $\begin{array}{l}56,34^{*} \\
(0,000)\end{array}$ \\
\hline Banco Estrangeiro & $\begin{array}{r}-80606030 \\
(0,742)\end{array}$ & - & $\begin{array}{r}-2,40^{*} \\
(0,001)\end{array}$ & $\begin{array}{l}-1,835^{*} \\
(0,001)\end{array}$ & $\begin{array}{l}27,57^{\star} \\
(0,083)\end{array}$ & $\begin{array}{l}26,86^{*} \\
(0,018)\end{array}$ \\
\hline № de Observações & 348 & 372 & 348 & 350 & 348 & 350 \\
\hline $\mathrm{R}^{2}$ ajustado & 0,129 & 0,158 & 0,348 & 0,361 & 0,469 & 0,475 \\
\hline Teste F & 3,71 & 24,29 & 10,79 & 20,78 & 17,17 & 29,79 \\
\hline Prob $>F$ & 0,000 & 0,000 & 0,000 & 0,000 & 0,000 & 0,000 \\
\hline Durbin-Watson & 0,698 & 0,657 & 1,89 & 1,87 & 1,79 & 1,79 \\
\hline
\end{tabular}

Obs: Utilizamos dummy de ano em todos os modelos. No caso do modelo Valor II, a dummy de ano significativa foi de 1893. No caso do modelo Juros II, as dummy de ano significativas foram de 1889 a 1892 e 1896 e 1898. Por fim, no caso do modelo Prazo II, as dummy de ano significativas foram de 1891 a 1893 e de 1896 a 1900.

A diferença entre o tipo de colateral, expressa pela variável terreno, não determinou as condições dos empréstimos. A existência ou não de companhia como medida de distinções entre os devedores foi significativa apenas para o valor. De modo oposto, os tipos de bancos produziram mudança no prazo e nos juros, porém não no valor da hipoteca. Finalmente, verificamos causa e consequência entre valor e juros, mas não entre valor e prazo. Assim, apesar da falta de informações do devedor e da garantia típica da própria atividade de crédito, esboçamos certo perfil dos empréstimos hipotecários na cidade de São Paulo. Na próxima seção, discutiremos os movimentos dos bancos no mercado hipotecário paulistano, em especial as alterações das condições de financiamento nessa época de grandes mudanças. 


\section{Dinâmica do Crédito Hipotecário}

Os anos da transição republicana foram favoráveis à expansão do crédito bancário e hipotecário urbano. A legislação facilitou a organização de sociedades anônimas e a política monetária expansionista do Encilhamento incrementou os financiamentos. Ao analisar a dinâmica das hipotecas bancárias no Gráfico l, notamos um expressivo crescimento nos primeiros anos republicanos. Como o recorte nesta seção consiste em comparações ao longo do tempo, marcado por fortes variações das taxas de câmbio e dos preços, realizamos a transformação dos valores nominais para o ano base de 1878 por meio de um índice de preços do atacado, proposto por Luiz Catão. ${ }^{50}$ Já no início do período em estudo, notamos um aumento do número de hipotecas e, posteriormente, dos valores reais transacionados. $\mathrm{O}$ auge da expansão ocorreu, em termos do número, de 1890 a 1892, e, em termos dos montantes, de 1890 a 1893.

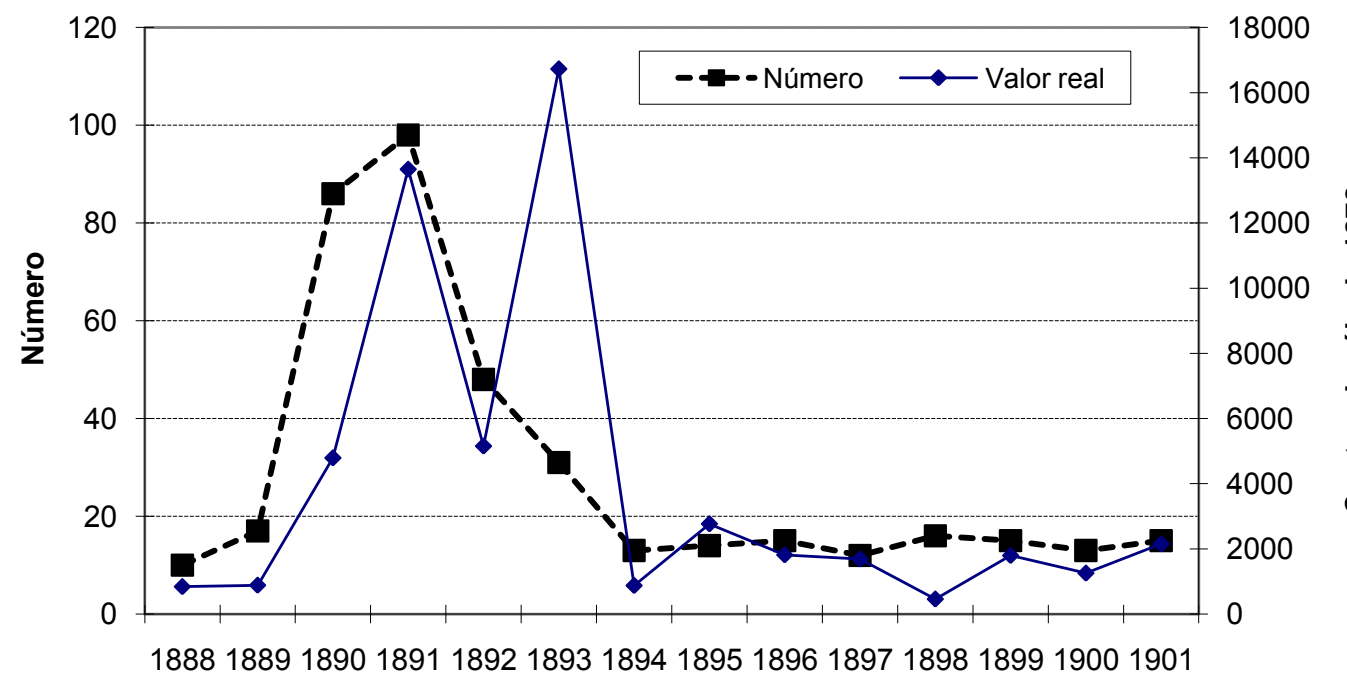

1888-1901)

A partir de 1894, estabilizou-se o número de transações executadas na capital e mesmo os valores retornaram a um patamar pouco superior ao existente antes de 1890. Este arrefecimento do mercado hipotecário das instituições bancárias decorreu da crise cafeeira, que se iniciou em meados dos anos 1890, e da política deflacionária, efetuada no final da década de 1890. Ao contrário das informações dos balanços contábeis acerca do estoque de ativos bancários, que não apontam

50 A escolha de 1878 decorreu da perspectiva do trabalho mais amplo de realizar comparações num período maior (1865 a 1901). 
uma retração significativa nesse último momento, o fluxo de registros das novas hipotecas na cidade de São Paulo revelou um declínio substancial tanto do número quanto dos valores negociados. Isto pode refletir uma mudança nas atividades dos bancos, talvez, nesse momento, mais voltadas ao crédito rural, mas o declínio em hipotecas urbanas da cidade de São Paulo mostra-se nítido. ${ }^{51}$

O prazo médio no período acompanhou o movimento de expansão e retração do mercado urbano, como pode ser observado no Gráfico 2. Os maiores vencimentos ocorreram para os anos de 1889 a 1892, declinando suavemente até o final do século. Nesse período de boom, o prazo médio atingiu quase nove anos, porém, ao final do período, chegou a pouco mais de dois anos, à exceção de 1901, por conta da forte atuação do Banque Belge de Préts Fonciers, respondendo por nove das quinze transações, com prazo de cerca de nove anos.

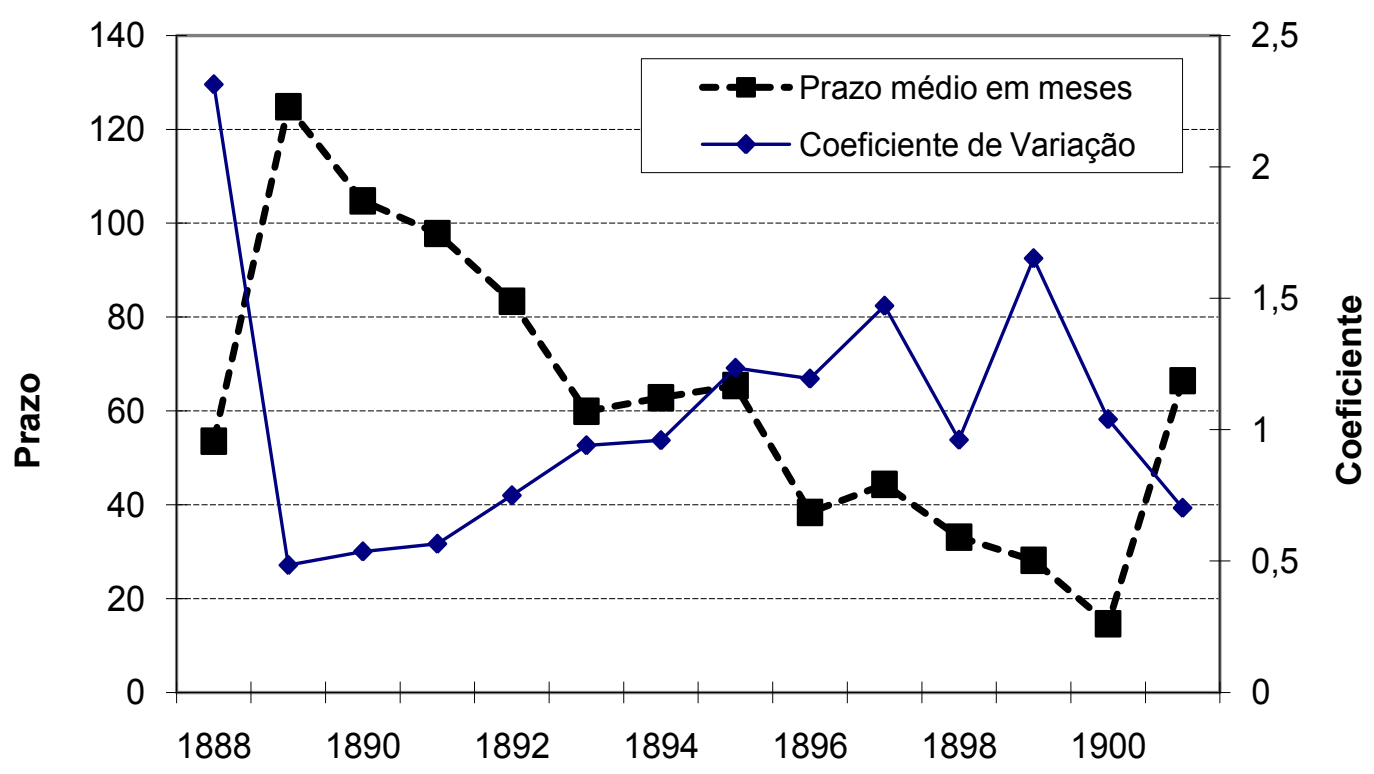

Gráfico 2 - Prazo Médio e Coeficiente de Variação (São Paulo, 1888-1901)

51 Não há nenhum estudo mais abrangente do mercado hipotecário na Província ou Estado de São Paulo como um todo; assim, não é possível falar com mais segurança sobre o efeito da crise cafeeira no mercado hipotecário rural. Tal estudo compreende planos futuros dos autores. 
No conjunto, a dinâmica de redução do prazo mostrou-se muito expressiva, com uma diferença entre os vencimentos dos dois momentos de mais de quatro vezes. Deste modo, notamos um progressivo aumento das decisões mais conservadoras em momentos menos favoráveis, ou seja, arriscaram menos. Por fim, o coeficiente de variação tendeu a apresentar um movimento oposto ao da média, salientando um aumento da dispersão dos prazos dos empréstimos, enquanto a média se reduz ao longo do período.

O movimento das taxas médias de juros acompanhou o dos prazos em sentido oposto, como pode ser observado no Gráfico 3. Verificamos as menores taxas para os anos de 1889 a 1892, ao redor de 7\% ao ano. A partir de 1894, os juros aumentaram para o patamar entre $9 \%$ e $10 \%$ ao ano, confirmando a mudança do mercado para uma situação mais conservadora. O coeficiente de variação dos juros mostrou-se inferior ao do prazo, demonstrando a menor variabilidade das taxas entre as transações. Assim, o mercado hipotecário como um todo se aproximou, ao longo do tempo, cada vez mais, das condições do crédito comercial.

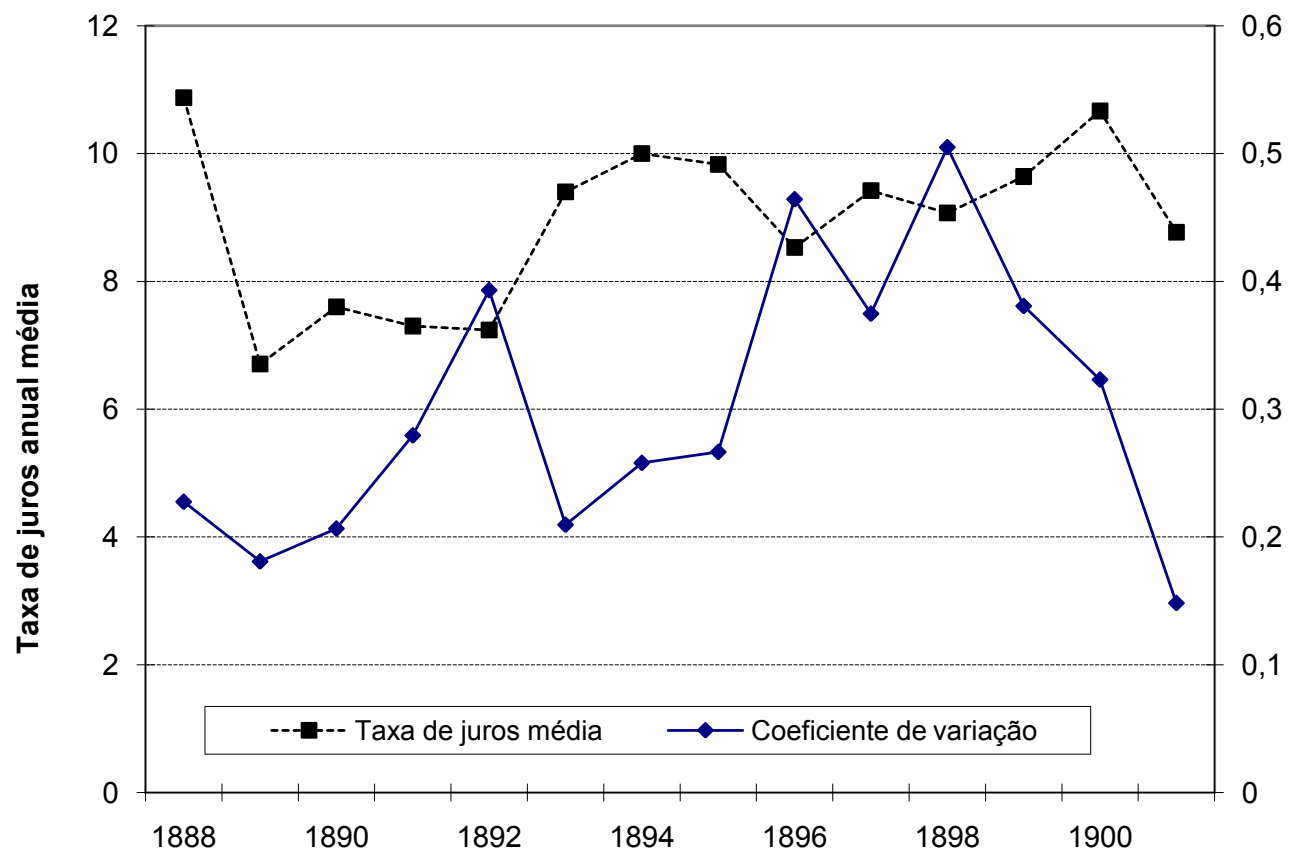

Gráfico 3 - Taxa de Juros e Coeficiente de Variação (São Paulo, 1888-1901) 
As tendências observadas nos gráficos acima abarcam três distintos modelos de comportamento, de acordo com o tipo de banco do nosso estudo. Ao iniciar a transição republicana (1888-1889), quando o setor foi dominado por instituições bancárias comerciais, o único banco hipotecário compreendeu sozinho 53,5\% dos valores das hipotecas registradas na cidade de São Paulo. Os bancos estrangeiros e comerciais domésticos dividiram o restante do mercado hipotecário em parcelas próximas - 23,3\% e 23,2\%, respectivamente. Estas informações revelaram certas características deste mercado emergente. Primeiro, a expansão institucional do setor bancário comercial foi compartilhada por instituições estrangeiras e domésticas. $\mathrm{Na}$ década 1880, já existiam sete bancos domésticos atuando na praça paulista e quatro estrangeiros, com valores de empréstimos totais semelhantes, como demonstrado na Tabela 1: 13 mil contos versus 9 mil contos. Não obstante os registros hipotecários revelarem uma divergência entre o número de transações efetuadas por domésticos e estrangeiros (9 e 2), o valor das hipotecas dos estrangeiros foi quase idêntico ao dos domésticos: 342 versus 343 contos, em termos nominais. Os ganhos de participação dos bancos domésticos, em detrimento dos estrangeiros, nos anos 1890, não foram previsíveis nos primeiros momentos da transição republicana. Segundo, os empréstimos hipotecários foram uma importante parte do mercado de crédito paulistano, desde o início das operações do primeiro banco hipotecário da província - o Banco de Crédito Real. Enquanto esse banco foi formado para prover crédito à agricultura, as informações dos seus balanços mostram que as suas novas hipotecas paulistanas, em 1889, representaram $13,5 \%$ do total do crédito hipotecário contabilizado ao final desse ano. Isto não foi atípico nos empréstimos, em virtude de os bancos comerciais emprestarem tanto a curto quanto a longo prazo. Dois bancos comerciais realizaram relativamente grandes empréstimos hipotecários ao final da década de 1880. De um lado, o Banco da Lavoura detinha, em 1888, uma proporção de $16,9 \%$ das novas hipotecas inscritas em relação aos seus empréstimos em carteira e, de outro, o English Bank (futuro British Bank) possuía uma participação de $18,1 \%$ em idêntico ano. ${ }^{52}$

No momento áureo da expansão do mercado (1890-1893), com o acréscimo de dois novos bancos universais ou hipotecários, a preponderância destas instituições no mercado hipotecário foi clara, pois detinham quase três quartos dos valores transacionados $(73,6 \%)$. Todo este aumento foi em detrimento dos bancos estrangeiros, cuja participação se reduziu para apenas $4,4 \%$ do mercado hipotecário, enquanto os comerciais domésticos emprestaram pouco menos de um quarto $(22,0 \%) .{ }^{53}$ As reformas da legislação de 1890, que facilitaram a formação de novas empresas domésticas, ajudaram certamente o ganho de mercado dos bancos domésticos em

52 Dados de balanços contábeis de instituições bancárias disponíveis pelos autores sob pedido.

53 Lembramos que nesta seção não consideramos o vultoso empréstimo da Companhia Paulista por meio do British Bank. 
relação aos estrangeiros. A expansão econômica do Encilhamento proporcionou a estes novos bancos um contexto otimista, justificando uma expansão paralela dos empréstimos hipotecários. Esta relativamente pequena participação de bancos comerciais domésticos e estrangeiros no mercado, nos primeiros anos republicanos, pode ser explicada pelo extraordinário crescimento das hipotecas dos dois maiores bancos hipotecários: Banco de Crédito Real e Banco União de São Paulo. Estes bancos registraram, juntos, 147 das 233 hipotecas urbanas, inscritas de 1890 a 1892, ou seja, quase dois terços. Destarte, estes dois bancos foram os financiadores mais importantes do mercado hipotecário paulistano. A importância relativa dos bancos universais ou hipotecários, no período do Encilhamento, mostrou-se superior no mercado hipotecário do que na totalidade da carteira de empréstimos contabilizada nos balanços (ver Tabela 1).

Se os bancos universais ou hipotecários dominaram o mercado hipotecário, isto decorreu mais do seu porte expressivo do que da ausência de concorrência dos bancos comerciais. Estes últimos bancos procuraram participar ativamente da expansão econômica dos primeiros anos da República. A sua participação foi mais esporádica e desigual do que a atividade dos bancos hipotecários, sugerindo que estes bancos se engajaram mais em empréstimos oportunos do que em um deslocamento concentrado para empréstimos a longo prazo. O Banco da Lavoura, formado na expansão dos anos 1880, revelou-se um bom exemplo de mudança neste mercado. O banco registrou, em 1888, uma única hipoteca correspondente a cerca de um sexto dos empréstimos em carteira e, em 1889, uma outra, no valor de menos de dois pontos percentuais. Nos anos seguintes, ele anotou sete hipotecas em 1890, compreendendo $13,5 \%$ da sua carteira, e, em 1891, três empréstimos, respondendo por 4,2\% do ativo. Estas proporções variaram em importância de menos de dois pontos percentuais a mais de treze de todos os seus empréstimos. Outra instituição, o Banco do Brasil/Banco Comercial e Agrícola, registrou variações mais fortes no empréstimo hipotecário. Efetuou um empréstimo na cidade em 1888, nenhum em 1889 e nove em 1890, oito em 1891, somente um em 1892 e nenhum mais no restante da década. Estas hipotecas também se alteraram de menos de um ponto percentual a mais de treze no valor dos empréstimos totais contabilizados.

Essa fase final da turbulenta transição republicana foi marcada pela crise da economia cafeeira, pela inflação, pela recessão e, posteriormente, pela deflação. Os anos de 1894 a 1901 foram um exercício de instabilidade para todos os bancos e seus clientes, no Brasil. Num ambiente de incerteza, observamos um declínio nos prazos e um crescimento das taxas de juros dos novos empréstimos hipotecários. Este perfil de empréstimos do final da década de 1890 é mais semelhante ao do banco comercial tradicional do que o dos empréstimos a prazo longo e juros reduzidos, que caracterizam os financiamentos dos bancos hipotecários típicos. Ademais, 
nosso estudo dos subgrupos mostra que os universais ou hipotecários reduziram fortemente a sua importância no mercado $(34,6 \%)$, enquanto a participação de todos os bancos comerciais ultrapassou a metade. Entre estes últimos, os bancos estrangeiros passaram a realizar a maior parcela dos valores emprestados por todos os bancos $(36,4 \%)$, mas os domésticos também aumentaram sua participação no mercado hipotecário $(29,0 \%)$.

Quando anotamos o volume de hipotecas por instituição bancária individual, verificamos que estes percentuais escondem como a crise enfraqueceu profundamente o mercado hipotecário paulistano. As porcentagens apresentadas no parágrafo precedente mostram, por exemplo, que a parcela do mercado possuída pelos bancos universais ou hipotecários diminuiu de $73,6 \%$ para $34,6 \%$. Contudo, estes percentuais não podem revelar o quanto se reduziu o número de novas hipotecas. Estes bancos, que registraram dezenas de empréstimos nos primeiros anos da República, anotaram somente três em 1895, e mais duas em 1899, chegando a 1901 sem o registro de nenhuma transação. Até a virada do século 20 , um dos dois bancos universais paulistanos deixou de registrar hipotecas novas por causa da crise. O Banco de Crédito Real faliu poucos anos depois. ${ }^{54} \mathrm{O}$ comando por bancos universais de um terço do mercado deveu-se simplesmente à sua tendência de registrar os empréstimos de maior montante do que seus competidores comerciais.

Juntos, os bancos comerciais tinham inscrito 35 hipotecas em 1890, outras 29 em 1891 e 19 em 1892, porém somente nove em 1895 e outras 13 em 1899 e 15 em 1901. Mesmo que sua participação no mercado de hipotecas urbanas fosse limitada, em comparação com sua atração no começo da década, os bancos comerciais registraram pelo menos três vezes mais o número de hipotecas do que os bancos universais ou hipotecários. Desta fonte de hipotecas dos bancos comerciais emergiu um perfil distinto, ao final dos anos 1890. Como apresentado antes, estes empréstimos bancários registraram-se a prazos mais curtos e a taxas de juros mais elevadas do que os financiamentos realizados pelos bancos universais ou hipotecários. A sua importância maior nos anos de crise do final da década alterou o perfil geral do mercado.

Finalmente, o ressurgimento dos bancos estrangeiros no mercado de São Paulo salientou-se no final do período de estudo. Como visto acima, estas instituições registraram menos de um vigésimo das hipotecas, em termos dos valores nos dias expansionistas do início dos anos 1890. Entretanto, para o fim da década, seus empréstimos perfizeram quase um quarto das hipotecas urbanas. Este ressurgimento mostrou-se expressivo em 1899, quando três bancos estrangeiros anotaram cinco

54 A falência deveu-se à importância dos empréstimos rurais no ativo do banco. Assim, ele assumiu a propriedade de diversos imóveis com pouca liquidez, com a crise do café. 
hipotecas de expressivo valor, representando, para cada um, de $12,3 \%$ a $31,7 \%$ dos empréstimos contabilizados em suas respectivas carteiras, ao final do ano. Em 1901, tal presença revelou-se amplamente dominante no mercado, perfazendo 13 das 15 hipotecas e respondendo por quase a totalidade dos valores. ${ }^{55}$ Este foi um investimento significativo numa economia que se encontrava em recessão profunda, provocada por uma política deflacionária do Ministro da Fazenda, Joaquim Murtinho. Possivelmente, estes empréstimos representavam um voto de confiança dos interesses estrangeiros no plano de estabilização de Murtinho, que os beneficiaria. ${ }^{56}$

\section{Considerações Finais}

Nossa pesquisa cruza balanços contábeis com registros hipotecários dos bancos a fim de investigar o perfil e o comportamento do crédito institucional de longo prazo, durante uma época crítica da história de São Paulo. A transição republicana foi um momento de estímulo para uma dramática expansão e diversificação econômica, em razão do boom da economia cafeeira. Este crescimento e esta ampliação do universo das atividades econômicas foram causa e consequência da elevação do crédito institucional. Enquanto a história do crédito formal foi bem estudada por Saes, Triner e Hanley, a relação entre o crédito formal e o mercado hipotecário é inexplorada. Este artigo tenta preencher esta lacuna, examinando os balanços contábeis de Hanley e os detalhados registros hipotecários de Marcondes, a fim de compreender como eles se relacionaram.

Este trabalho revelou vários resultados que permitem melhor entendimento sobre um tema pouco estudado, mas de grande relevância para a expansão econômica de São Paulo, ao final do século 19. Primeiro, bancos universais ou hipotecários foram a fonte de recursos mais importante dos empréstimos do mercado de hipotecas paulistanas, ao final do século 19. Durante os anos 1890 da transição republicana, nenhum outro tipo de instituição conseguiu substituir ou deslocar estas instituições como a principal fonte de financiamento hipotecário na cidade de São Paulo. Isto sugere que as reformas legais que criaram estas instituições ofereceram um benefício real para a economia. Contudo, não mantiveram papel semelhante na passagem do século 19 para o 20, apontando uma mudança expressiva em relação ao início da década.

Segundo, embora a maioria dos empréstimos hipotecários fosse realizada por bancos universais ou hipotecários, os bancos comerciais foram ativos neste mercado. Bancos

55 Isto sem considerar o empréstimo extraordinário do National Trust Company Limited.

56 No entanto, estes bancos não se encontravam imunes. Todos os bancos estrangeiros em São Paulo foram severamente restringidos pela crise e, como resultado, o Banque Française faliu. 
comerciais emprestaram dinheiro em hipotecas por períodos mais longos do que era típico para esta espécie de instituição. Mesmo os bancos comerciais estrangeiros entraram em menor monta neste mercado, especialmente no auge do Encilhamento, apesar das advertências da matriz para as transações com horizonte de tempo longo. Isto sugere que o mercado hipotecário foi suficientemente lucrativo para induzir estas instituições mais conservadoras a assumirem algum grau de risco. E foi especialmente mais acentuado ao final do período, quando os bancos estrangeiros foram muito ativos, talvez incentivados pela política deflacionária introduzida para revalorizar a moeda brasileira. Assim, eles assumiram parcela crescente do mercado na passagem do século 19 para o 20, inclusive com empréstimos de menores valores.

Em terceiro lugar, a ascensão e o declínio da participação dos bancos comerciais no mercado hipotecário urbano acompanharam a expansão e a retração da economia paulista ao longo dos anos 1890, sugerindo que estes banqueiros sabiam ser prudentes nos seus empréstimos. Os novos empréstimos hipotecários inscritos por bancos comerciais, na última parte da década de 1890, foram em prazos relativamente mais curtos do que aqueles financiamentos registrados nos anos exuberantes do Encilhamento.

Em quarto lugar, os empréstimos hipotecários pelos bancos universais ou hipotecários foram efetuados tipicamente por prazos mais longos e a taxas de juros menores do que os empréstimos hipotecários inscritos por outros tipos de bancos. Quando os bancos universais ou hipotecários escolheram reduzir dramaticamente a inscrição de novos empréstimos, ao final da década de 1890, deixaram o mercado sem alternativa quanto a prazos mais longos/taxas menores que estimulassem o desenvolvimento econômico. Ainda que a recessão do fim do século não eliminasse a participação dos bancos no mercado hipotecário, encolheram-se fortemente nesse mercado e realizaram as condições mais custosas para os devedores. No início do século 20, estes bancos deixaram de atuar no mercado hipotecário, sendo a última atuação a do Crédito Real, em 1899, e a do União, em 1900. Tal comportamento mostra a tendência de forte retração das suas atividades financeiras, culminando com a falência do primeiro e o abandono da carteira bancária em favor de uma concentração em produção fabril do segundo.

Ao final, não obstante a dificuldade de caracterizar o devedor e o colateral, procuramos avaliar as relações entre as condições dos empréstimos (valor, juros e prazo) e as características do devedor e do tipo de garantia e de banco. Verificamos que o valor não se relacionou ao prazo, mas apenas aos juros e se o devedor era uma companhia ou não. Os juros foram explicados pelo valor, pelo prazo e pelo tipo de banco. Finalmente, o prazo explicou-se por meio dos juros e do tipo de banco. A diferença entre o tipo de garantia, expressa mediante a presença de terreno sem 
construção ou outra ocupação, não se mostrou relevante para explicar as condições. Deste modo, começamos a esboçar um padrão dos empréstimos hipotecários efetuados pelos bancos naquela época.

\section{Referências}

BARBOSA, Rui. Relatório do ministro da fazenda. Rio de Janeiro: Imprensa Nacional, 1891.

BRASIL. Coleção de Leis e Decretos. Rio de Janeiro: Typographia Nacional, vários anos.

CATÃO, Luis A. V. A new wholesale price index for Brazil during the period 1870-1913. Revista Brasileira de Economia, v. 46, n. 4, p. 519-533, out./dez. 1992.

FRANCO, Gustavo. Reforma monetária e instabilidade durante a transição republicana. 1983. Dissertação (Mestrado em Economia) - PUC-RJ, Rio de Janeiro: BNDES, 1983.

. A primeira década republicana. In: ABREU, Marcelo de Paiva (Org.). A ordem do progresso: cem anos de política econômica republicana 1889-1989. Rio de Janeiro: Campus, 1990.

GUIMARÃES, Carlos Gabriel. O Império e o crédito hipotecário na segunda metade do século XIX: os casos do Banco Rural e Hipotecário do Rio de Janeiro e do Banco Comercial e Agrícola na década de 1850. In: GUIMARÃES, Elione Silva; MOTTA, Márcia Maria Menedes. (Org.). Campos em disputa: história agrária e companhia. São Paulo: Annablume, 2007, p. 13-40.

HANLEY, Anne G. Native Capital: financial institutions and economic development in São Paulo, Brazil, 1850-1920. Stanford: Stanford University Press, 2005.

JACOMINO, Sérgio. Cadastro, registro e algumas confusões históricas. In: II SEMINÁRIO DE DIREITO NOTARIAL E REGISTRAL DE SÃO PAULO. Lins: Instituto de Registro Imobiliário do Brasil, 2006.

JOSLIN, David. A Century of Banking in Latin America: to commemorate the centenary in 1962 of the Bank of London \& South America Limited. London: Oxford University Press, 1963.

LERIAS, Reinéro Antonio. Encilhamento e a cidade de São Paulo: 1890-1891. 1988. Dissertação (Mestrado em História) - FFLCH/USP, 1988.

MARCONDES, Renato Leite; MADURO JÚNIOR, Paulo Rogério Rodrigues. Crédito hipotecário em São Paulo: evidências para um núcleo urbano em expansão (1865-1890). In: XXXIII ENCONTRO NACIONAL DE ECONOMIA (ANPEC). Natal: ANPEC, 2005.

PIÑEIRO, Théo Lobarinhas. A carteira hipotecária do Banco do Brasil: os conflitos em torno do crédito agrícola no II Reinado. In: GUIMARÃES, Elione Silva; 
MOTTA, Márcia Maria Menedes. (Org.). Campos em disputa: história agrária e companhia. São Paulo: Annablume, 2007, p. 41-62.

SAES, Flávio Azevedo Marques de. Crédito e bancos no desenvolvimento da economia paulista (1850-1930). São Paulo: IPE/USP, 1986.

SCHULZ, John. A crise financeira da abolição (1875-1901). São Paulo: Edusp/ Instituto Fernand Braudel, 1996.

TRINER, Gail. Banking and economic development: Brazil, 1889-1930. New York: Palgrave, 2000. 


\section{ANEXO A}

\begin{tabular}{|c|c|c|c|c|c|c|}
\hline Nome do Banco & 1886 & 1889 & 1890 & 1892 & 1895 & 1901 \\
\hline \multicolumn{7}{|l|}{ Bancos Comerciais na Capital } \\
\hline Banco do Brasil/Banco Construtor e Agrícola & $x$ & $x$ & $x$ & $x$ & $x$ & $x$ \\
\hline Banco Mercantil de Santos & $x$ & $x$ & $x$ & $\mathrm{X}$ & $x$ & $\mathrm{x}$ \\
\hline Banco Comercial de São Paulo & $x$ & $x$ & & & & \\
\hline Banco da Lavoura & $x$ & $x$ & & & & \\
\hline Banco Popular/Banco dos Lavradores & & $x$ & & $x$ & $x$ & $x$ \\
\hline Banco de São Paulo & & $x$ & $x$ & $x$ & $\mathrm{X}$ & $x$ \\
\hline Banco do Comércio e Indústria de São Paulo & & & $x$ & $x$ & $x$ & $x$ \\
\hline Banco Commercial e Italiano & & & & & & $x$ \\
\hline \multicolumn{7}{|l|}{ Bancos Comerciais no Interior } \\
\hline Banco de Araraquara & & & & $x$ & $x$ & \\
\hline Banco de Piracicaba & & & & $x$ & $x$ & $x$ \\
\hline Banco de Ribeirão Preto & & & & $x$ & $x$ & $x$ \\
\hline Banco União de São Carlos & & & & $x$ & $x$ & $x$ \\
\hline Banco Melhoramentos de Jaú & & & & $x$ & $x$ & $x$ \\
\hline Banco Regional de Mococa & & & & & & $x$ \\
\hline Banco Indústria e Comércio de Piracicaba & & & & & & $x$ \\
\hline \multicolumn{7}{|l|}{ Bancos Estrangeiros } \\
\hline English Bank of Rio de Janeiro-Santos & $x$ & $x$ & & & & \\
\hline $\begin{array}{l}\text { English Bank of Rio de Janeiro-São Paulo/ } \\
\text { British Bank of South America }\end{array}$ & $x$ & $x$ & $x$ & $x$ & $x$ & $x$ \\
\hline London and Brazilian Bank & $x$ & $x$ & $x$ & $x$ & $x$ & $x$ \\
\hline Brasilianishe Bank fur Deutschland & & & & & $x$ & $x$ \\
\hline Banque Française & & & & & & $x$ \\
\hline \multicolumn{7}{|l|}{ Bancos Universais } \\
\hline Banco de Crédito Real & $x$ & $x$ & $x$ & $x$ & $x$ & $x$ \\
\hline Banco União de São Paulo & & & $x$ & $x$ & $x$ & \\
\hline Banco de Santos & & & $x$ & $X$ & $x$ & $x$ \\
\hline
\end{tabular}

\section{Quadro A1 - Relação de Bancos na Amostra (Tabela 1)}

Obs: Valores estimados para os seguintes: (1890) English Bank e London and Brazilian Bank; (1892) Banco de Ribeirão Preto e London and Brazilian Bank; (1895) Banco Melhoramentos de Jaú; (1901) Banco União de São Paulo. 